\title{
Microstructure and microwave dielectric properties of $\left(\mathrm{Zn}_{1-x} \mathrm{Mg}_{x}\right)_{2} \mathrm{SiO}_{4}$ ceramics
}

\author{
BO LI*, YING YUAN, SHUREN ZHANG and HONGMEI JIANG \\ State Key Laboratory of Electronic Thin Films and Integrated Devices, \\ University of Electronic Science and Technology of China, Chengdu 610054, P.R. China
}

MS received 6 January 2010; revised 26 February 2010

\begin{abstract}
ZnMg})_{2} \mathrm{SiO}_{4}$ powders was prepared by the sol-gel process, and the microstructure and dielectric properties of $\left(\mathrm{Zn}_{1-x} \mathrm{Mg}_{x}\right)_{2} \mathrm{SiO}_{4}$ microwave materials were investigated systematically. TG-DSC and XRD analyzes for gels indicate that the $(\mathrm{ZnMg})_{2} \mathrm{SiO}_{4}$ with pure willemite phase could be obtained at low temperature of $850^{\circ} \mathrm{C}$. Further, XRD illustrates that just small amounts of $\mathrm{Mg}$ can be incorporated into $\mathrm{Zn}_{2} \mathrm{SiO}_{4}$ lattice, and the solid solution limit of $\mathrm{Mg}$ in $\mathrm{Zn}_{2} \mathrm{SiO}_{4}$ is about $x=0 \cdot 1$. By appropriate $\mathrm{Mg}$ substitution for $\mathrm{Zn}$, the sintering range is widened and the sintering temperature of $\mathrm{Zn}_{2} \mathrm{SiO}_{4}$ ceramics can be lowered effectively. SEM shows that $\mathrm{Mg}$-substitution for $\mathrm{Zn}$ can promote the grain growth of $\mathrm{Zn}_{2} \mathrm{SiO}_{4}$. Moreover, the microwave dielectric properties strongly depended on the substitution content of $\mathrm{Mg}$ and sintering temperatures. $\left(\mathrm{Zn}_{0.8} \mathrm{Mg}_{0.2}\right)_{2} \mathrm{SiO}_{4}$ dielectrics sintered at $1170^{\circ} \mathrm{C}$ show the condense microstructure with small uniform grains and best microwave properties: $\varepsilon_{\mathrm{r}}=6 \cdot 3, Q \times f=189800 \mathrm{GHz}$ and $\tau_{\mathrm{f}}=-63 \mathrm{ppm} /{ }^{\circ} \mathrm{C}$.
\end{abstract}

Keywords. Willemite $\left(\mathrm{Zn}_{2} \mathrm{SiO}_{4}\right)$; forsterite $\left(\mathrm{Mg}_{2} \mathrm{SiO}_{4}\right)$; microwave ceramics; dielectric property; microstructure; millimetre-wave frequency.

\section{Introduction}

With the rapid development of mobile communication and radar systems, the utilized frequency has also correspondingly increased to millimetre-wave, where large quantity of information could be transported with rapid speed. The resonators and filters for such high-band microwave applications strongly require the microwave dielectrics with a very low dielectric constant $\left(\varepsilon_{\mathrm{r}}\right)$, a highquality factor $(Q)$, and a near-zero temperature coefficient of resonant frequency $\left(\tau_{\mathrm{f}}\right)$. In recent years, several material systems with low $\varepsilon_{\mathrm{r}}$ and high- $Q$ value such as $\mathrm{Al}_{2} \mathrm{O}_{3}$, $\mathrm{Mg}_{2} \mathrm{SiO}_{4}$ and $\mathrm{CaWO}_{4}$ have been investigated (Park et al 2001; Ohsato et al 2003; Tsunooka et al 2003). In addition, a newly developed $\mathrm{Zn}_{2} \mathrm{SiO}_{4}$ ceramics is considered to be good candidate material for high performance millimetre-wave devices.

Guo et al (2006) first reported that $\mathrm{Zn}_{2} \mathrm{SiO}_{4}$ ceramics prepared by solid-state method sintered at $1340^{\circ} \mathrm{C}$ exhibited excellent dielectric properties: $\varepsilon_{\mathrm{r}}=6.6, Q \times f=$ $219,000 \mathrm{GHz}$. However, $\mathrm{Zn}_{2} \mathrm{SiO}_{4}$ showed a high $\tau_{\mathrm{f}}$ of $-61 \mathrm{ppm} /{ }^{\circ} \mathrm{C}$. The $11 \mathrm{wt} \% \quad \mathrm{TiO}_{2}$ modified $\mathrm{Zn}_{2} \mathrm{SiO}_{4}$ ceramics sintered at $1250^{\circ} \mathrm{C}$ showed a near-zero $\tau_{\mathrm{f}}$ value of $1.0 \mathrm{ppm} /{ }^{\circ} \mathrm{C}$ with $\varepsilon_{\mathrm{r}}$ of $9 \cdot 3, Q \times f$ value of $113,000 \mathrm{GHz}$. Nguyen et al (2007) studied the effect of $\mathrm{Zn} / \mathrm{Si}$ ratio on

\footnotetext{
*Author for correspondence (lbuestc@163.com)
}

the microstructure and microwave properties of $\mathrm{Zn}_{2} \mathrm{SiO}_{4}$ ceramics, and found that the ceramics with nominal composition $\mathrm{Zn}_{1.8} \mathrm{SiO}_{3.8}$ sintered at $1300^{\circ} \mathrm{C}$ exhibited improved microwave dielectric properties of $\varepsilon_{\mathrm{r}}=6 \cdot 6, Q \times$ $f=147,000 \mathrm{GHz}$, and $\tau_{\mathrm{f}}=-22 \mathrm{ppm} /{ }^{\circ} \mathrm{C}$. Besides, Song et al (2008) improved the $Q \times f$ value of $\mathrm{Zn}_{2} \mathrm{SiO}_{4}$ ceramics by $\mathrm{Mg}^{2+}$ substituting for $\mathrm{Zn}^{2+}$ and $\left(\mathrm{Zn}_{0.6} \mathrm{Mg}_{0.4}\right) \mathrm{Si}_{2} \mathrm{O}_{4}$ ceramics sintered at $1250^{\circ} \mathrm{C}$ achieved the dielectric properties: $\varepsilon_{\mathrm{r}}=6 \cdot 6, Q \times f=95,650 \mathrm{GHz}$ and $\tau_{\mathrm{f}}=-60 \mathrm{ppm} /{ }^{\circ} \mathrm{C}$. Accordingly, the high sintering temperature and large negative $\tau_{\mathrm{f}}$ value of $\mathrm{Zn}_{2} \mathrm{SiO}_{4}$-based ceramics put constraints on its application as microwave materials. However, $\mathrm{Mg}_{2} \mathrm{SiO}_{4}$ dielectrics recently have been lowered by the addition of suitable low melting glasses for possible LTCC applications (Sasikala et al 2008, 2010).

It is well known that sol-gel process is an efficient technique for the produce of the ceramics, due to the good mixing of starting materials and relatively low reaction temperature resulting in more homogeneous products than those obtained by direct solid state reactions. Dong et al (2008) reported that the sol-gel-prepared $\mathrm{Zn}_{2} \mathrm{SiO}_{4}$ ceramics sintered at $1325^{\circ} \mathrm{C}$ showed dielectric properties: $\varepsilon_{\mathrm{r}}=6.6, Q \times f=198,400 \mathrm{GHz}$, and $\tau_{\mathrm{f}}=-41.6 \mathrm{ppm} /{ }^{\circ} \mathrm{C}$. In this work, $\left(\mathrm{Zn}_{1-x} \mathrm{Mg}_{x}\right)_{2} \mathrm{SiO}_{4}$ ceramics with good microwave performance were synthesized by sol-gel procedure at such lower temperature of $1170^{\circ} \mathrm{C}$. Moreover, the influence of $\mathrm{Mg}$-substituting content on the structural and microwave dielectric properties of $\left(\mathrm{Zn}_{1-x} \mathrm{Mg}_{x}\right)_{2} \mathrm{SiO}_{4}$ system was investigated systematically. 


\section{Experimental}

\subsection{Sample preparation}

$\left(\mathrm{Zn}_{1-x} \mathrm{Mg}_{x}\right)_{2} \mathrm{SiO}_{4}(x=0 \cdot 1,0 \cdot 2,0 \cdot 3,0 \cdot 4)$ was prepared with sol-gel method. According to the designed composition, $\mathrm{ZnO}$ and $\mathrm{MgCO}_{3}$ were dissolved in $\mathrm{HNO}_{3}$ and deionized water, and then poured into ethanol and ethyl silicate $\left(\left(\mathrm{C}_{2} \mathrm{H}_{5}\right)_{4} \mathrm{SiO}_{4}, \mathrm{TEOS}\right)$. The volume ratio of $\mathrm{C}_{2} \mathrm{H}_{5} \mathrm{OH}$ to TEOS was $1: 1$ and the $\mathrm{pH}$ value was adjusted to near 2 . Highly transparent sols were obtained after vigorous stirring, and transparent gels could be formed at $90^{\circ} \mathrm{C}$ for $3 \mathrm{~h}$. Dried gels were achieved by heating the wet gels at $100^{\circ} \mathrm{C}$ for $24 \mathrm{~h}$. Then the xerogels were calcined at 700 $1000^{\circ} \mathrm{C}$ for $2 \mathrm{~h}$. The calcined powders were ball milled in alcohol for $24 \mathrm{~h}$ with zirconia balls. The dried powders with $10 \mathrm{wt} \%$ PVA were granulated and pressed into pellets $(10 \mathrm{~mm}$ in diameter and $7 \mathrm{~mm}$ in height), and then sintered at temperatures of $1130-1190^{\circ} \mathrm{C}$ for $2 \mathrm{~h}$.

\subsection{Characteristics analysis}

Thermoanalysis of dry gels was carried out using a TGDSC thermoanalyzer (Netzsch STA 449C) from 29 to $1350^{\circ} \mathrm{C}$ at heating rate of $10^{\circ} \mathrm{C} / \mathrm{min}$. The crystalline phases of the calcined powders and sintered ceramics were identified by X-ray diffraction analysis (XRD, Philips X'Pert-MPD) using $\mathrm{Cu}-\mathrm{K} \alpha$ radiation. Microstructural observation of the sintered ceramics was performed by scanning electron microscopy (SEM, Hitachi S-530) equipped with energy dispersive spectroscopy (EDS). The dielectric characteristics at microwave frequencies were measured by the Hakki-Coleman dielectric resonator method. A system combined with an Agilent network analyzer E8363A was employed in the measurement. The $Q \times f$ factor was used to evaluate the loss quality, where $f$ is the resonant frequency. The temperature coefficient of resonant frequency $\left(\tau_{\mathrm{f}}\right)$ was measured by the open cavity method in the temperature range from 25 to $75^{\circ} \mathrm{C}$ and was defined as

$$
\tau_{\mathrm{f}}=\frac{f_{75}-f_{25}}{50 \cdot f_{25}},
$$

where $f_{25}$ and $f_{75}$ are the resonant frequency at 25 and $75^{\circ} \mathrm{C}$, respectively.

\section{Results and discussion}

TG and DSC curves of the $\left(\mathrm{Zn}_{0.8} \mathrm{Mg}_{0.2}\right)_{2} \mathrm{SiO}_{4}$ dried gel are drawn in figure 1 . A $56.1 \%$ weight loss is observed in the thermogravimetric curve of the $\left(\mathrm{Zn}_{0.8} \mathrm{Mg}_{0.2}\right)_{2} \mathrm{SiO}_{4}$ gel in the temperature range between 29 and $600^{\circ} \mathrm{C}$. This is due to the removal of hydration water and the decomposition of the nitrate and $\mathrm{Si}(\mathrm{OH})_{4}$. Moreover, there is no weight change when the temperature is higher than $700^{\circ} \mathrm{C}$. From DSC pattern, there are two endothermic peaks at about 152.1 and $322.8^{\circ} \mathrm{C}$, respectively, and one exothermic peak around $777.9^{\circ} \mathrm{C}$. The first endothermic peak at $152 \cdot 1^{\circ} \mathrm{C}$ indicates the dehydration of $\mathrm{Zn}\left(\mathrm{NO}_{3}\right)_{2} \cdot x \mathrm{H}_{2} \mathrm{O}$ and hydrated silica. The next endothermic peak around $322.8^{\circ} \mathrm{C}$ is connected to the decomposition of nitrate radical $\left(\mathrm{NO}_{3}\right)^{-}$. The exothermic peak located at $777.9^{\circ} \mathrm{C}$ may be caused by the crystallization of $\mathrm{ZnO}$ as well as the phase formation of $\mathrm{Zn}_{2} \mathrm{SiO}_{4}$.

XRD was used to investigate the change in crystalline phase during the preparation of $\left(\mathrm{Zn}_{0.8} \mathrm{Mg}_{0.2}\right)_{2} \mathrm{SiO}_{4}$. According to DSC curve, the obtained gel was treated at $700,800,850$ and $1000^{\circ} \mathrm{C}$, and their XRD patterns are shown in figure 2. The XRD pattern of gel at $700^{\circ} \mathrm{C}$ shows no obvious diffraction peaks, which indicates that the composite is amorphous. At $800^{\circ} \mathrm{C}$, the diffraction peaks almost belong to $\mathrm{Zn}_{2} \mathrm{SiO}_{4}$ main phase, while a few $\mathrm{ZnO}$ second phase appears. This demonstrates that the exothermic peak at $777.9^{\circ} \mathrm{C}$ is caused by the phase formation of $\mathrm{Zn}_{2} \mathrm{SiO}_{4}$ together with $\mathrm{ZnO}$. It could be seen that the pure $(\mathrm{ZnMg})_{2} \mathrm{SiO}_{4}$ phase is formed at low temperature of about $850^{\circ} \mathrm{C}$, but the secondary phase $\mathrm{ZnO}$ disappears. The intensity of diffraction peaks of $\mathrm{Zn}_{2} \mathrm{SiO}_{4}$ became stronger as the calcining temperature increases to $1000^{\circ} \mathrm{C}$. Thus, the dry gel for $\left(\mathrm{Zn}_{0.8} \mathrm{Mg}_{0.2}\right)_{2} \mathrm{SiO}_{4}$ should be heat-treated at $850^{\circ} \mathrm{C}$ to obtain the pure $(\mathrm{ZnMg})_{2} \mathrm{SiO}_{4}$ phase and produce the active fine powders used in the following experiments.

Figure 3 shows the XRD patterns of $\left(\mathrm{Zn}_{1-x} \mathrm{Mg}_{x}\right)_{2} \mathrm{SiO}_{4}$ $(x=0-0 \cdot 4)$ ceramics sintered at $1170^{\circ} \mathrm{C}$ for $2 \mathrm{~h}$. Only diffraction peaks of willemite phase are observed for specimens with $x=0-0 \cdot 1$, which can be indexed as a trigonal structure. Nguyen et al (2007) reported that the $\mathrm{ZnO}$ secondary phase was formed in the $\mathrm{Zn}_{2} \mathrm{SiO}_{4}$ ceramics, which would result in the low $Q \times f$ value. But the unwanted $\mathrm{ZnO}$ phase is not found for all the present specimens. A few diffraction peaks of the secondary

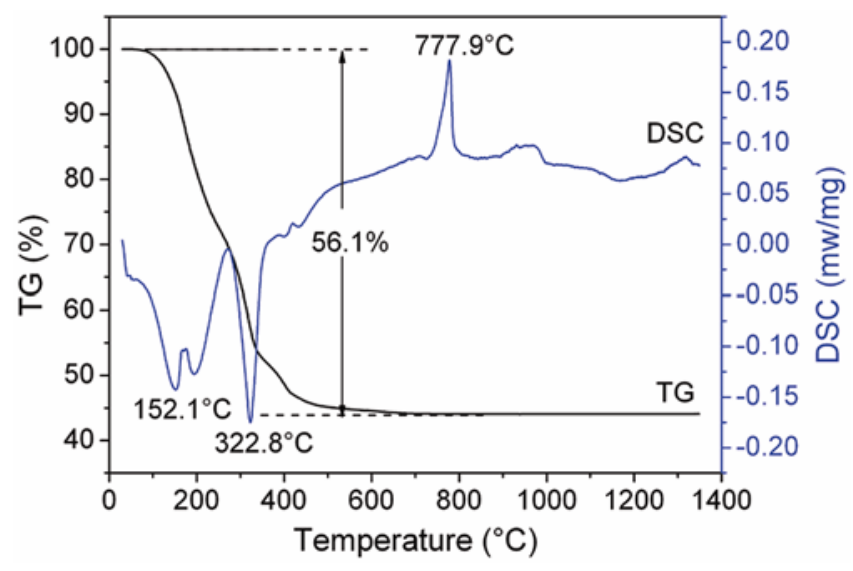

Figure 1. TG-DSC curves of $\left(\mathrm{Zn}_{0.8} \mathrm{Mg}_{0.2}\right)_{2} \mathrm{SiO}_{4}$ gel from 29 to $1350^{\circ} \mathrm{C}$. 
phase $\mathrm{Mg}_{2} \mathrm{SiO}_{4}$ appear accompanying the main phase $\mathrm{Zn}_{2} \mathrm{SiO}_{4}$ with the increase of $\mathrm{Mg}$ content $(x=0 \cdot 2-0 \cdot 3)$, and the obvious co-presence of two such crystal phases is determined at $x=0 \cdot 4$. At the same time, the peak intensity of $\mathrm{Zn}_{2} \mathrm{SiO}_{4}$ phase is weakened and that of $\mathrm{Mg}_{2} \mathrm{SiO}_{4}$ phase is enhanced significantly. Therefore, the solid solution limit of $\mathrm{Mg}$ ions in $\mathrm{Zn}_{2} \mathrm{SiO}_{4}$ is about $x=0 \cdot 1$ on the basis of XRD results here. However, Song et al (2008) previously found that the $\mathrm{Mg}_{2} \mathrm{SiO}_{4}$ secondary phase disappears at $x=0.95$ for $\left(\mathrm{Mg}_{1-x} \mathrm{Zn}_{x}\right)_{2} \mathrm{SiO}_{4}$, which agrees well with that reported by Segnit and Holland (1965). This result indicates that the solubility limit of $\mathrm{Mg}$ ions in the $\mathrm{Zn}_{2} \mathrm{SiO}_{4}$ lattice could be somewhat influenced by the preparation method used as well.

In fact, the small solid solution limit of $\mathrm{Mg}$ in $\mathrm{Zn}_{2} \mathrm{SiO}_{4}$ is because of the large difference between the crystal structure of $\mathrm{Zn}_{2} \mathrm{SiO}_{4}$ and $\mathrm{Mg}_{2} \mathrm{SiO}_{4}$. Though $\mathrm{Zn}_{2} \mathrm{SiO}_{4}$ and

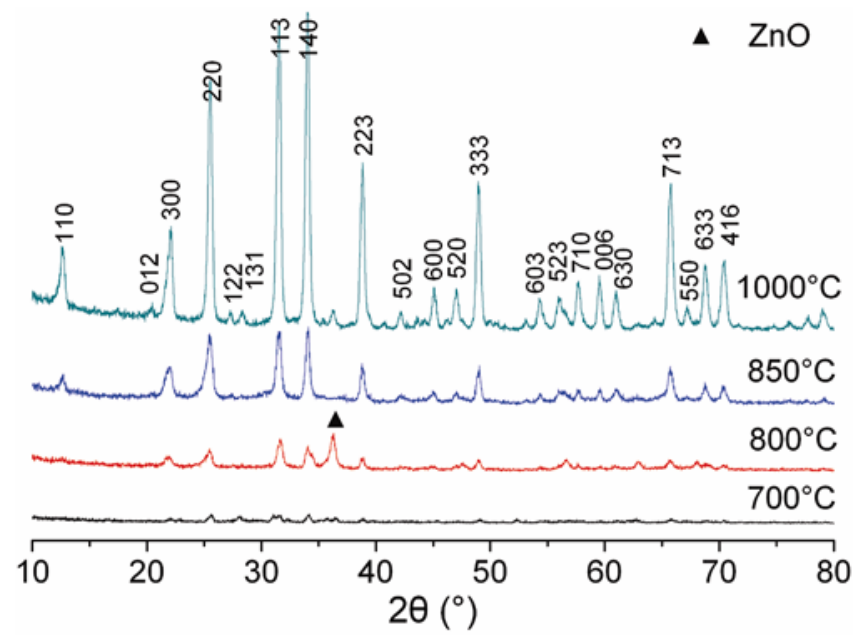

Figure 2. $\mathrm{XRD}$ patterns of $\left(\mathrm{Zn}_{0.8} \mathrm{Mg}_{0.2}\right)_{2} \mathrm{SiO}_{4}$ gel calcined at different temperature.

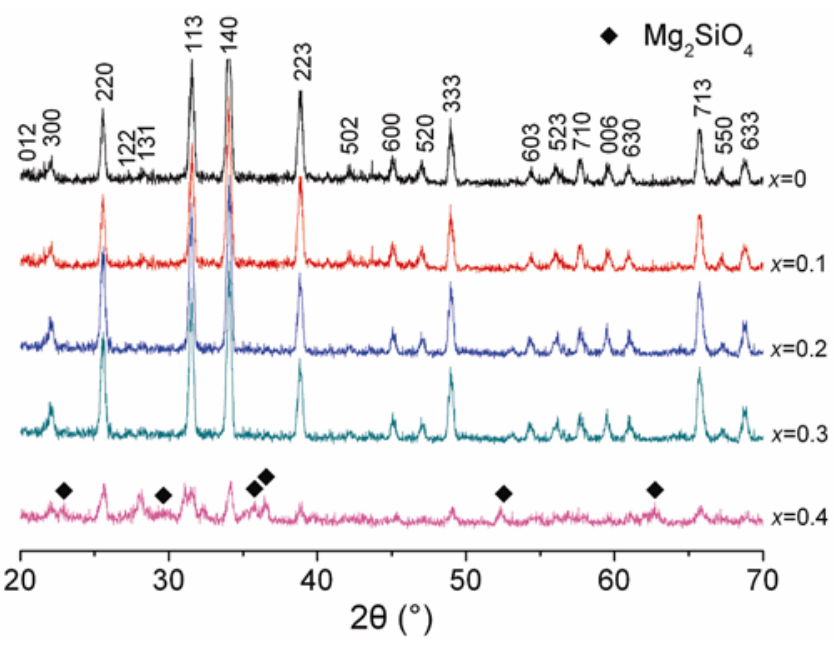

Figure 3. XRD patterns of $\left(\mathrm{Zn}_{1-x} \mathrm{Mg}_{x}\right)_{2} \mathrm{SiO}_{4}$ ceramics sintered at $1170^{\circ} \mathrm{C}$.
$\mathrm{Mg}_{2} \mathrm{SiO}_{4}$ are both island silicate compounds with similar formula, the former generally known as willemite, has a rhombohedral structure belonging to space group $R \overline{3}$, and the latter, known as forsterite, has an orthorhombic structure belonging to space group Pmnb (Chang et al 1999; Horiuchi and Sawamoto 1981). $\mathrm{Zn}_{2} \mathrm{SiO}_{4}$ is built on connection of $\mathrm{Zn}-\mathrm{O}$ tetrahedron with $\mathrm{Si}-\mathrm{O}$ tetrahedron by sharing vertex, and $\mathrm{Mg}_{2} \mathrm{SiO}_{4}$ is composed of connection of $\mathrm{Mg}-\mathrm{O}$ octahedron with $\mathrm{Si}-\mathrm{O}$ tetrahedron by sharing vertex and edge. Accordingly, just small amount of $\mathrm{Mg}$ can be incorporated into $\mathrm{Zn}_{2} \mathrm{SiO}_{4}$ lattice and substitute zinc ions. That is, the solid solution $\left(\mathrm{Zn}_{1-x} \mathrm{Mg}_{x}\right)_{2} \mathrm{SiO}_{4}$ without any other phases could be formed at $x<0 \cdot 2$.

In the previous literatures, it has been reported that the preparation temperature of $\mathrm{Zn}_{2} \mathrm{SiO}_{4}$ and $(\mathrm{ZnMg})_{2} \mathrm{SiO}_{4}$ via the solid state reaction is usually higher than $1280^{\circ} \mathrm{C}$ (Guo et al 2006; Nguyen et al 2007; Song et al 2008). But in the case of the sol-gel processing method, the $\left(\mathrm{Zn}_{1-x} \mathrm{Mg}_{x}\right)_{2} \mathrm{SiO}_{4}$ ceramics can be sintered at the temperatures lower than $1200^{\circ} \mathrm{C}$ due to the fine powders with high activity. Figure 4 shows the SEM photographs of $\left(\mathrm{Zn}_{1-x} \mathrm{Mg}_{x}\right)_{2} \mathrm{SiO}_{4}$ ceramics sintered at $1170^{\circ} \mathrm{C}$. It is clearly seen that the microstructures of the $(\mathrm{ZnMg})_{2} \mathrm{SiO}_{4}$ materials change markedly with the doping content of $\mathrm{Mg}$. The spheroidic grains are small $(1-3 \mu \mathrm{m})$ and uniformly distributed for samples with $x=0 \cdot 1-0 \cdot 2$. However, the presence of white spots shown in figures $4 \mathrm{~b}-\mathrm{d}$ is confirmed by EDS analysis to be $\mathrm{Mg}_{2} \mathrm{SiO}_{4}$, which is consistent with the result from XRD. Moreover, with $\mathrm{Mg}$ content up to $0 \cdot 3$, the grains grew rapidly and two kinds of grains including spheroidic grains and stick grains are observed clearly. These phenomena indicate that the introduction of $\mathrm{Mg}$ in $\mathrm{Zn}_{2} \mathrm{SiO}_{4}$ could accelerate the grain growth of $\mathrm{Zn}_{2} \mathrm{SiO}_{4}$, and elongate the grains at the same time.

Figure 5 shows the dielectric constant $\left(\varepsilon_{\mathrm{r}}\right)$ of specimens with different $\mathrm{Mg}$ content as a function of sintering temperature. For samples with $x \leq 0 \cdot 3$, the $\varepsilon_{\mathrm{r}}$ value slightly increases at first with increasing the firing temperature from 1130 to $1150^{\circ} \mathrm{C}$. A large increase in $\varepsilon_{\mathrm{r}}$ value is observed at a temperature between 1150 and $1170^{\circ} \mathrm{C}$, and then only small change occurs with further increase in the sintering temperature. It is understood that higher density will lead to higher dielectric constant owing to lower porosity in willemite-based ceramics (Guo et al 2006; Nguyen et al 2007). This suggests that the rapid densification for $\left(\mathrm{Zn}_{1-x} \mathrm{Mg}_{x}\right)_{2} \mathrm{SiO}_{4}$ ceramics $x$ with $\leq 0.3$ occurred at a temperature above $1150^{\circ} \mathrm{C}$, and then density nearly saturated at above $1170^{\circ} \mathrm{C}$. For sample with $x=0.4$, the variation of $\varepsilon_{\mathrm{r}}$ value versus temperature is not significant $(6 \cdot 1-6 \cdot 2)$, suggesting that the firing temperature range is wide, that is, it can be sintered at a lower temperature. It is found that $\mathrm{Mg}$-substitution for $\mathrm{Zn}$ can decrease the sintering temperature of $\mathrm{Zn}_{2} \mathrm{SiO}_{4}$ ceramics. Moreover, it can be seen that $\varepsilon_{\mathrm{r}}$ values increase greatly with 

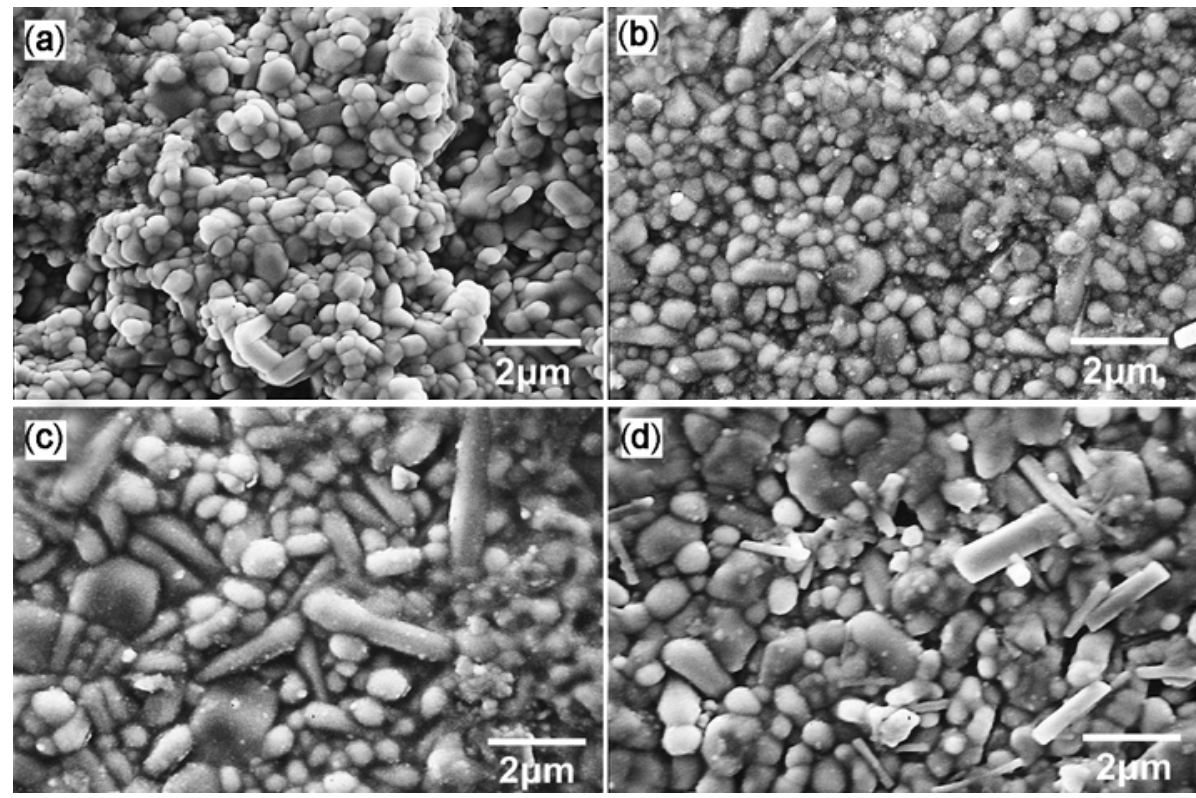

Figure 4. SEM photographs of $\left(\mathrm{Zn}_{1-x} \mathrm{Mg}_{x}\right)_{2} \mathrm{SiO}_{4}$ ceramics sintered at $1170^{\circ} \mathrm{C}$ : (a) $x=0 \cdot 1 ;$ (b) $x=0 \cdot 2 ;$ (c) $x=0 \cdot 3 ;$ (d) $x=0 \cdot 4$.

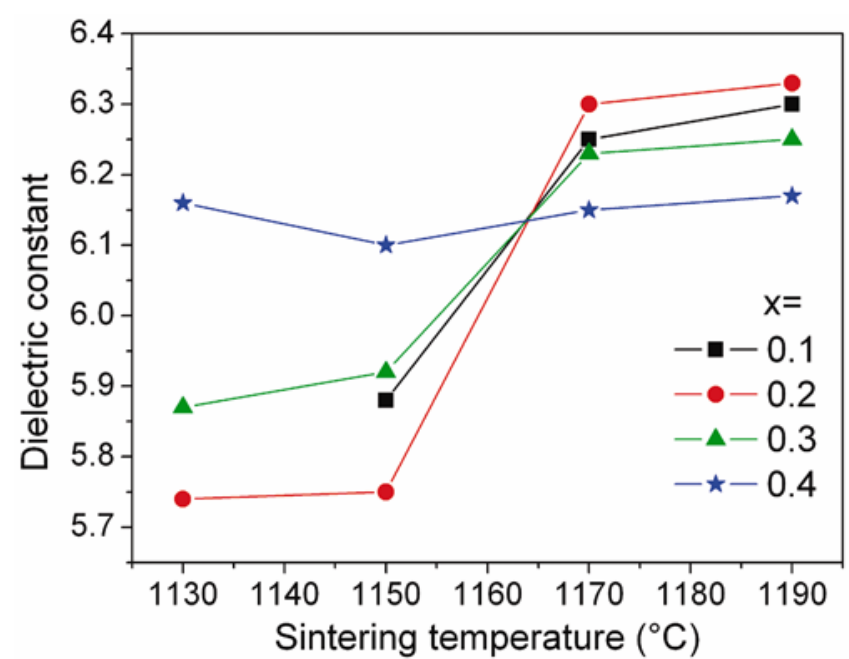

Figure 5. Sintering temperature dependence of dielectric constant for $\left(\mathrm{Zn}_{1-x} \mathrm{Mg}_{x}\right)_{2} \mathrm{SiO}_{4}$ ceramics.

increasing $x$ for samples fired at such low temperature range $\left(1130-1150^{\circ} \mathrm{C}\right)$. When specimens sintered at the temperature higher than $1170^{\circ} \mathrm{C}$, firstly, the $\varepsilon_{\mathrm{r}}$ increases to the maximum value at $x=0 \cdot 2$, and then turns to decrease steady with increasing $x$. It implies that the densification temperature of $\left(\mathrm{Zn}_{1-x} \mathrm{Mg}_{x}\right)_{2} \mathrm{SiO}_{4}$ ceramics decreases from 1190 to $1130^{\circ} \mathrm{C}$ with increasing $x$ up to $0 \cdot 4$. Therefore, it suggests that it is difficult for $\mathrm{Zn}_{2} \mathrm{SiO}_{4}$ ceramics to obtain a dense microstructure and its sintering range is very narrow. By appropriate $\mathrm{Mg}^{2+}$ substituting for $\mathrm{Zn}^{2+}$, the sintering range is widened and the sintering temperature of $\mathrm{Zn}_{2} \mathrm{SiO}_{4}$ ceramics can be lowered from 1190 to $1130^{\circ} \mathrm{C}$.

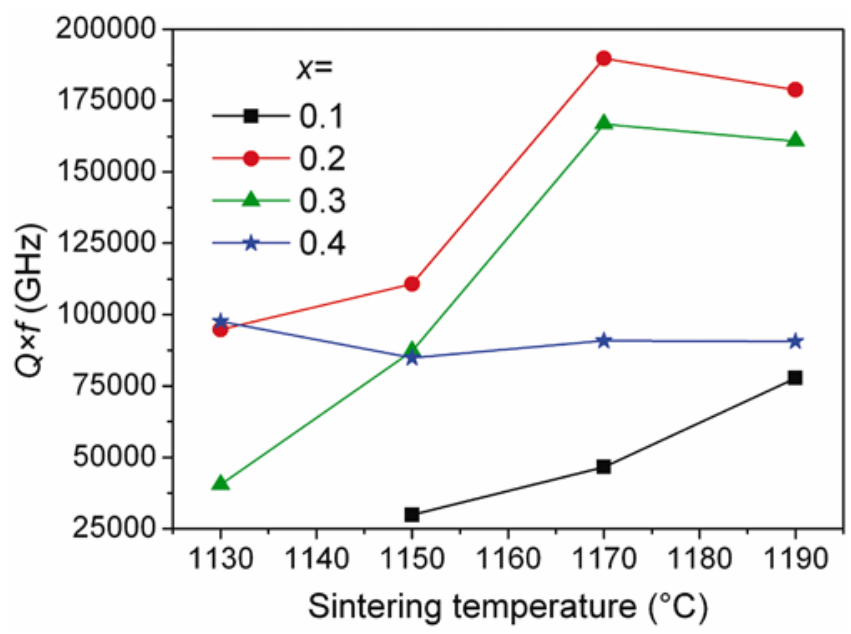

Figure 6. $Q \times f$ of $\left(\mathrm{Zn}_{1-x} \mathrm{Mg}_{x}\right)_{2} \mathrm{SiO}_{4}$ ceramics as a function of sintering temperature.

Figure 6 illustrates the sintering temperature dependence of $Q \times f$ value for $\left(\mathrm{Zn}_{1-x} \mathrm{Mg}_{x}\right)_{2} \mathrm{SiO}_{4}$ ceramics. It can be observed that the $Q \times f$ value increases gradually with increasing temperature for the sample with $x=0 \cdot 1$. For samples with $x=0 \cdot 2-0 \cdot 3$, with the increase of firing temperature, $Q \times f$ values also increase and reach the maximum (about $189,800 \mathrm{GHz}$ ) at $1170^{\circ} \mathrm{C}$, then decrease slightly. For the sample with $x=0 \cdot 4$, the $Q \times f$ shows insignificant variation as a function of temperature between 85,000 and $100,000 \mathrm{GHz}$. It is found that the $Q \times f$ value approximately shows the same tendency of the dielectric constant, but there is still some difference between them. In fact, quality factor $(Q)$ is affected by 


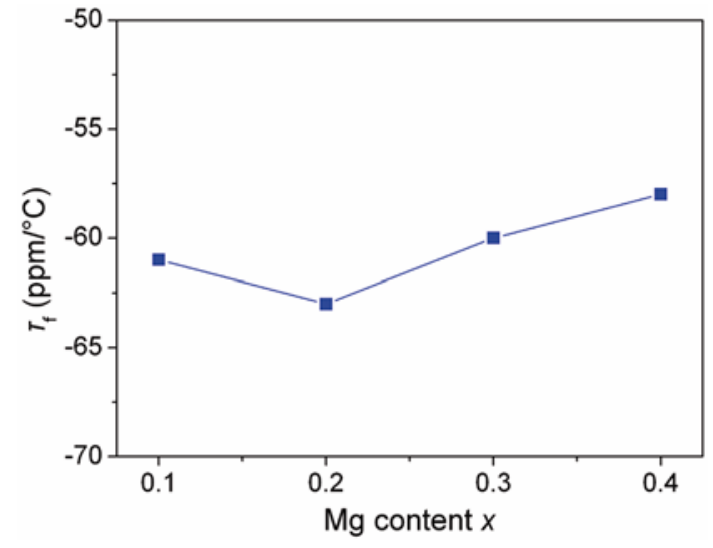

Figure 7. The dependence of the $\tau_{\mathrm{f}}$ value of $\left(\mathrm{Zn}_{1-x} \mathrm{Mg}_{x}\right)_{2} \mathrm{SiO}_{4}$ on $\mathrm{Mg}$ content sintered $1170^{\circ} \mathrm{C}$.

impurities, secondary phases, porosity and oxygen vacancy etc, although density plays an important role in controlling the dielectric loss. Furthermore, Huang et al (2001) reported that the $Q \times f$ is independent of density or porosity as the density is higher than $90 \%$ of theoretical density. Thus, the $Q \times f$ shows relative lower value at $x=0 \cdot 4$, possibly due to the increase of the secondary phase $\mathrm{Mg}_{2} \mathrm{SiO}_{4}(Q \times f=50,000-60,000)$. In addition, the specimen containing $x=0.2 \mathrm{Mg}$ exhibits higher $Q \times f$ value than other specimens in the temperature range from 1130 to $1190^{\circ} \mathrm{C}$, which is ascribed to the high density and minor amount of the secondary phase $\mathrm{Mg}_{2} \mathrm{SiO}_{4}$ in the $\left(\mathrm{Zn}_{1-x} \mathrm{Mg}_{x}\right)_{2} \mathrm{SiO}_{4}$ as $x=0 \cdot 2$.

The variation of $\tau_{\mathrm{f}}$ value with the $\mathrm{Mg}$-substituting content in $\left(\mathrm{Zn}_{1-x} \mathrm{Mg}_{x}\right)_{2} \mathrm{SiO}_{4}$ sintered $1170^{\circ} \mathrm{C}$ is shown in figure 7 . It can be seen clearly that $\tau_{\mathrm{f}}$ values vary slightly ( -63 to $-58 \mathrm{ppm} /{ }^{\circ} \mathrm{C}$ ) as the substituting content of $\mathrm{Mg}$ increases. But $\tau_{\mathrm{f}}$ value initially decreases with increasing $x$, and then turns to increase when $x$ exceeds $0 \cdot 2$, which is attributed to the increase of $\mathrm{Mg}_{2} \mathrm{SiO}_{4}$ with comparatively higher $\tau_{\mathrm{f}}\left(-50 \mathrm{ppm} /{ }^{\circ} \mathrm{C}\right)$ than $\mathrm{Zn}_{2} \mathrm{SiO}_{4}\left(\tau_{\mathrm{f}}=-61 \mathrm{ppm} /{ }^{\circ} \mathrm{C}\right)$. From the above experimental data, it can be concluded that $\left(\mathrm{Zn}_{0.8} \mathrm{Mg}_{0.2}\right)_{2} \mathrm{SiO}_{4}$ dielectrics via sol-gel process sintered at lower temperature of $1170^{\circ} \mathrm{C}$ has the condense microstructure and shows better microwave properties: $\varepsilon_{\mathrm{r}}=6 \cdot 3, Q \times f=189,800 \mathrm{GHz}$ and $\tau_{\mathrm{f}}=-63 \mathrm{ppm} /{ }^{\circ} \mathrm{C}$, compared with the higher temperature sintered samples prepared by solid state method. Therefore, it is much easier to lower the sintering temperature of $(\mathrm{ZnMg})_{2} \mathrm{SiO}_{4}$ ceramics below $960^{\circ} \mathrm{C}$ based on the sol-gel preparation above, and further investigation is required.

\section{Conclusions}

$\left(\mathrm{Zn}_{1-x} \mathrm{Mg}_{x}\right)_{2} \mathrm{SiO}_{4}$ powders was prepared by the sol-gel process, and the thermal behaviour and phase transformation of the gels were investigated by the TG-DSC and $\mathrm{XRD}$ analyses, which indicated that pure $(\mathrm{ZnMg})_{2} \mathrm{SiO}_{4}$ phase could be formed at low temperature of $850^{\circ} \mathrm{C}$. Further, the structural and microwave dielectric properties of $\left(\mathrm{Zn}_{1-x} \mathrm{Mg}_{x}\right)_{2} \mathrm{SiO}_{4}$ system was investigated. XRD indicated that the solid solution limit of $\mathrm{Mg}$ ions in $\mathrm{Zn}_{2} \mathrm{SiO}_{4}$ is small (about $x=0 \cdot 1$ ), because of the differing crystal structure between $\mathrm{Zn}_{2} \mathrm{SiO}_{4}$ and $\mathrm{Mg}_{2} \mathrm{SiO}_{4}$. SEM showed that the introduction of $\mathrm{Mg}$ in $\mathrm{Zn}_{2} \mathrm{SiO}_{4}$ could accelerate the grain growth of $\mathrm{Zn}_{2} \mathrm{SiO}_{4}$, and decrease the sintering temperature of $\mathrm{Zn}_{2} \mathrm{SiO}_{4}$ ceramics. The microwave dielectric properties changes markedly with the chemical composition ( $\mathrm{Mg}$ content) and sintering conditions. $\left(\mathrm{Zn}_{0.8} \mathrm{Mg}_{0.2}\right)_{2} \mathrm{SiO}_{4}$ ceramics sintered at $1170^{\circ} \mathrm{C}$ exhibited the condense microstructure with fine grains and the good microwave dielectric properties of $\varepsilon_{\mathrm{r}}=6 \cdot 3, Q \times f=$ $189,800 \mathrm{GHz}$ and $\tau_{\mathrm{f}}=-63 \mathrm{ppm} /{ }^{\circ} \mathrm{C}$.

\section{References}

Chang H J et al 1999 J. Kore, Phys. Soc. 34545

Dong M, Yue Z, Zhuang H, Meng S and Li L $2008 \mathrm{~J}$. Am. Ceram. Soc. 913981

Guo Y, Ohsato H and Kakimoto K -I 2006 J. Eur. Ceram. Soc. 261827

Horiuchi H and Sawamoto H 1981 Am. Miner. 66568

Huang C -L and Weng M -H 2001 Mater. Res. Bull. 362741

Nguyen N -H, Lim J -B, Nahmw S, Paik J -H and Kim J -H 2007 J. Am. Ceram. Soc. 903127

Ohsato H, Tsunooka T, Ohishi Y, Miyauchi Y, Ando M and Kakimoto K 2003 J. Korean Ceram. Soc. 40350

Park I -H, Kim B -S, Kim K -Y and Kim B -H 2001 Jpn. J. Appl. Phys. 404956

Sasikala T S, Suma M N, Mohananb P, Pavithran C and Sebastian M T 2008 J. Alloys Compd. 461555

Sasikala T S, Pavithran C and Sebastian M T 2010 J. Mater. Sci.: Mater. Electron. 21141

Segnit E R and Holland A E 1965 J. Am. Ceram. Soc. 48409

Song K X, Chen X M and Zheng C W 2008 Ceram. Int. 34917

Tsunooka T, Andou M, Higashida Y, Sugiura H and Ohsato H 2003 J. Eur. Ceram. Soc. 232573 